\title{
Diversification and Economic Growth in Nigeria (1981-2016): An Econometric Approach Based on Ordinary Least Squares (OLS)
}

\author{
Valentine Joseph Owan ${ }^{1 *}$, Victor Chijioke Ndibe ${ }^{2}$, Chidera Catherine Anyanwu ${ }^{3}$
}

\author{
${ }^{1}$ Department of Educational Management, University of Calabar, Calabar, NIGERIA \\ ${ }^{2}$ Department of Economics, University of Calabar, Calabar, NIGERIA \\ ${ }^{3}$ Department of Economics, Imo State University, Owerri, NIGERIA \\ *Corresponding Author: owanvalentine@gmail.com
}

Citation: Owan, V. J., Ndibe, V. C. and Anyanwu, C. C. (2020). Diversification and Economic Growth in Nigeria (1981-2016): An Econometric Approach Based on Ordinary Least Squares (OLS). European Journal of Sustainable Development Research, 4(4), em0131. https://doi.org/10.29333/ejosdr/8285

\section{ARTICLE INFO}

Received: 28 Mar. 2020

Accepted: 16 May 2020

\begin{abstract}
Economic diversification has been the glamour of successive administrations in Nigeria, especially amidst the dwindling oil-revenue in recent years, which has resulted from the fluctuations in world crude oil prices. This study aims at investigating the impact of diversifying the economy on the economic growth in Nigeria. Secondary data on GDP growth rate as a proxy for economic growth, non-oil GDP as a proxy for GDP diversification, non-oil export as a proxy for export diversification, investment and exchange rate, between 1981 and 2016, were adopted in the study. An econometric approach of Ordinary Least Squares (OLS) was adopted to empirically analyze the collected data and the result revealed that non-oil gross domestic product impacted positively and significantly on economic growth while exchange rate had an inverse but significant nexus on economic growth in Nigeria, within the period covered in the study. However, non-oil export and investment impacted positively but insignificantly on economic growth in Nigeria. The study recommends the encouragement of increased productivity in the real sector as well as the adoption of stable and favourable exchange rate policies by the government in order to accelerate economic growth in Nigeria.
\end{abstract}

Keywords: diversification, economy, growth, Nigeria, GDP, OLS

\section{INTRODUCTION}

The Nigerian economy was dominated by commercial activities and exports prior to independence in 1960 as there was no viable industrial sector. Gaining independence, agricultural activities served as the pivot around the sustenance of the Nigerian economy. Agriculture showed its efficacy by contributing to the GDP by $65 \%$ despite the swings in world prices (Jide, 2017). Thus, it was through Agriculture that revenues were raised that facilitated the importation of capital goods and raw materials from foreign nations through international trade. Sufficient food was produced by peasant farmers which were enough not only for domestic consumption but for export as well. Jide (2017) added that there were infrastructural developments by the governments through the surplus realized from the marketing boards for prospective economic advancement. The policy was formulated to improve export activities as a means of guaranteeing development (Ekpo and Umoh, 2014).

Post-civil war, there was a switch in the export structure as activities migrated from agriculture-based to oil-based, implying a gross and significant reduction in the contribution of the agricultural sector to the economy (Olaleye, Edun, and Taiwo, 2013). As a means of protecting the economy due to the threats from the fluctuations of world oil prices, and as a means of boosting largescale exports of agricultural products, the government eliminated taxes on the export and sales of agricultural commodities. However, high import tariffs were imposed as a means of discouraging imports for domestic agricultural productivity to thrive. Oyedije (1986) explained that this approach was very adopted in between earlier periods of 1970 and 1980 . With the production of oil in large commercial quantities, high oil prices between 1976 and 1981 meant that the government's foreign earnings from oil exports increased. Exports earnings from agricultural (which used to be the bedrock of the economy) were dwarfed by earnings from oil exports. Consequently, the government expanded and some physical infrastructures such as roads, airports, seaports, shipping lines, and a national electricity power grid system, etc., were built.

The ensuing problems far outweighed the benefits. Oil exploration led to environmental degradation and devastation in the Niger Delta region, oil wealth also demobilized the Nigerian people. The agricultural (which once was the bedrock and pivot around which other sectors rallied) began attracting lesser government attention, thereby leading to its neglect. Local production of goods and services plummeted; rapid urbanization led to slum development and crime. Massive importation and consumption 
of foreign goods turned Nigeria into a huge market for foreign producers. This led to massive unemployment, underemployment and poverty rates which are worsened by population explosion. The mismanagement of the agricultural sector coupled infrastructural problems saw a decline in the Nigerian export prowess of cash crops (e.g. groundnut, cashew, cocoa, timber, oil palm, rubber, among others). Although before the oil boom in 1970, these agricultural products constituted a significant portion (70\%) of Nigeria's export commodities.

In recent times, Nigeria is no longer considered a strong nation when it comes to the exports of some agricultural products (e.g. groundnut, rubber, cocoa and palm oil). An intriguing fact is that Nigeria has fallen down in the pecking order as the largest producer of poultry in Africa, with production dropping from 40,000,000 birds annually to a meagre 18,000,000 birds (Daily Independent, 2015). Agriculture has been relegated through neglection, poorly conceived policies of the government, and partial presence of social amenities such as good storage facilities, effective water supply, motorable roads, consistent power supply and many others. To address these issues, economic diversification has been one of the major yearnings of successive political administrations in Nigeria for over three decades now. Although attempts and progress were made, the efforts appear to have been futile as only meagre results in real terms seem to have been recorded.

Economic diversification can bring about many benefits such as expanding the export base of the country. Thereby increasing export earnings, create much-needed employment opportunities in order to absorb an increasing number of the teeming unemployed population, development and growth of potentials in untapped or underutilized sectors of the economy. Despite all the reforms aimed at developing the non-oil sector, a large chunk of raw materials, consumer- and producer-goods are still importreliant. Today, the poor exports of non-oil products are the norm while the county is stagnated growing in crucial sectors like tourism and textile production. Nigeria has therefore been unable to achieve the dynamic economy for which potentials abound but remain untapped. The agricultural sector has been relegated despite its efficacy to employ a large labour force (reducing unemployment) and provide a vent of surplus for domestic consumption and foreign earnings. As a result, a higher percentage of the populace are still living in struggles far below the poverty line (mostly in rural areas), while Nigeria herself is still grappling with problems of food security and unemployment.

One of Nigeria's attempts at diversifying the economy was the building of a virile industrial base through import substitution which depended on importing processed materials for assembling. However, the strategy merely bequeathed to the nation a number of assembly plants that were dependent on Completely Knockdown (CKD) components imported from industrialized nations while essential materials needed for domestic production in different sectors of the manufacturing industry were still being imported. The oil boom in Nigeria also led to the deterioration of human resource management. For failing to effectively diversify its economy and make concerted efforts towards developing other critical non-oil sectors (which has the potential to absorb its huge human resources), Nigeria has suffered from continued loss of skilled manpower as many graduates of higher education are not employed, or seek greener pastures in other nations.

The persistent abysmal performance of the non-oil sector, as well as the dangers bordering around the external sector, are imminent. This puts a call for an urgent reassessment of Nigeria's economic diversification policies and their implementation. It is very important for policymakers to adopt a shift in Nigeria's industrialization policy in line with modern trends. This would take advantage of untapped and underutilized potentials present in the non-oil sector, putting Nigeria on track towards sustainable economic development. The need to transform the economic mindset of Nigeria from an over oil-reliant to a multi-sector focus cannot be overemphasized. This is very important considering the limited safety characterised by total reliance on oil, due to international price dynamics and fluctuations which can put the county at risks at the macroeconomic level. Such risks include a fall in the demand for goods and services, an increase in the prices of commodities, production fall, and foreign reserves overburden (Olorunfemi and Raheem, 2008).

To achieve sustainable growth and development, Nigeria must mobilize massive local financing and create transparent institutions that encourage large-scale investments in agriculture, manufacturing, education, healthcare and training of its population. The Nigerian economy usually experiences a downward trend whenever there is a decline in the price of oil leading to poor foreign earnings (Uzonwanne, 2015). Imminently, if the Nigerian government pays attention to diversifying the economy, it could lead to sustainable economic growth. This is because increased diversification minimises the chances of uncertainty and volatility in the world oil market; job creation (especially in the private sector) and economic productivity increases; and the economy will cruise towards sustainable growth (Uzonwanne, 2015). Initially, attempts to diversify the Nigerian economy into other sectors such as the manufacturing sector, took the Import Substitution Industrialization (ISI) approach. Thus, the establishment of steel rolling plants and automobile assembly plants; creation of export processing zones; amongst others were part of the initiative.

Diversification does not occur in a vacuum, thus, having an enabling environment that makes diversification possible is very pertinent (Suberu, et al., 2015). Several key drivers were necessary to diversify the economy including investment; a competitive exchange rate; trade and industrial policies; a dynamic growth framework; macroeconomic stability; institutional variables (including good governance); an expansionary but disciplined fiscal blueprint; as well as the absence of conflict and corruption. Furthermore, some scholars maintained that various sectors including agriculture, education, manufacturing, hospitality, tourism and mining and the knowledge economy holds the key to Nigeria's diversification (Offem, Aniah, Agunwa, and Owan, 2017; Suberu, et al., 2015). Over the years successive Nigeria regimes have formulated and implemented various policies aimed at growing the non-oil sector. Varying degrees of progress, as well as failures, have been recorded along the way.

Oil provides a huge chunk of Nigeria's revenue and accounts for about $95 \%$ of its export's earnings. By providing large revenue streams in good times, this is good news; but the bad news is that in times of dwindling oil prices, the economy suffers from cyclical fluctuations, which bears negatively on government spending, resulting in fiscal deficits. It is known already that oil can be used to reduce a country's dependence on oil by investing profits in projects in other sectors (Agbaeze, Udeh, \& Onwuka, 2015). To 
Ojiabor (2014), it is very important for Nigeria to invest and diversify resources into critical sectors (especially in raising manufacturing industries), which would stop her from exporting valuable raw materials overseas. These materials could be transformed into something more precious domestically, creating jobs for Nigerians at the same time - multiplying the benefit to the national economy. In order for Nigeria's economy to become a truly diversified economy - one with expanded varieties of determinants of income and employment - consistent and impactful investments must be made in the various sectors that make up the non-oil sector.

This would reduce over-dependence on the oil sector, and ensure a relatively more stable economy, which would be less sensitive to the wider fluctuations associated with economies with one dominant industry. This study was designed therefore, to assess and show with empirical evidence, the effect economic diversification has on the growth in Nigeria. This paper was chiefly designed to assess diversification and the economic growth of Nigeria covering the period $1981-2016$. From the main objective, we derive the specific objectives as follows: to analyse the effect of GDP diversification on the economic growth of Nigeria; to determine the nexus between non-oil export diversification and economic growth in Nigeria.

\section{Research Hypotheses}

Based on the above-stated objectives, the following research hypotheses are formulated as follows.

$\mathrm{H}_{\circ 1}$ : GDP diversification proxy by non-oil export does not significantly affect the economic growth in Nigeria

$\mathrm{H}_{\mathrm{o2}}$ : Export diversification proxy by non-oil export has no significant effect on the economic growth in Nigeria

\section{LITERATURE REVIEW}

\section{Economic Diversification}

Generally, the term "economic diversification" is used to explain a process in which a country makes efforts towards boosting the range of economic outputs produced annually, through different production channels. It can also be seen as the process of investing in various sectors of an economy so that a failure in one sector, or an economic slump affecting one sector, would not have an adverse effect on the rest of the economy. Some scholars posit that growth and development are plausible in a diversified economy when savings from surplus sectors are mobilized into deficit sectors of the economy (Eko, Utting, and Onun, 2013). According to Olaleye, et al. (2013), Nigeria has intensified efforts to improve the non-oil sector as a step towards diversification through some macroeconomic policy framework. These policies possessed attributes of protectionism, trade liberalization and export promotion. The authors cited the establishment of some agencies (such as Nigerian Export-Import Bank [NEXIM] and Nigerian Export Promotion Council [NEPC]) as further efforts made to implement the formulated policies effectively (Olaleye, et al, 2013).

Since the 1970s, Nigeria's development has been tied to its dependence on oil, which accounts for about $90 \%$ of its export's earnings. This overdependence on oil makes the Nigerian economy very vulnerable to economic fluctuations resulting from oil price instability in the world market. It is therefore critical for Nigeria to embark on an earnest journey of diversifying her economy, by increasing its export base and making the most from the pool of natural resources available through efficient exploitation. Production and export should be covered in Nigeria's diversification approach including robust manufacturing, processing of agricultural products, production of other non-agro-related goods, sophisticated industrial goods and other services (World Bank, 2000).

Over the years, successive Nigerian governments have made frantic efforts at diversifying the economy through policy formulation, institutional support as well as policy implementation in different sectors of the economy. Many developing countries are characterized by the problem of poor economic diversification. Traditionally, many developing nations including Nigeria, produce on large-scale, primary commodities which are subject of price swings and climate variability to a significant extent. To take maximum advantage of her endowment of a large-base of natural resources, there is need for Nigeria to diversify her export activities. This way, the economy of Nigeria would witness stability and compete favourably with other world economic powers.

The importance of diversification has been argued and established as the pivot for sustainable economic growth. Some authors maintain that it is very vital in providing employment opportunities through the development of industries that are exportoriented. For instance, Uzonwanne (2015) posits that economic diversification requires full inclusion and active participation of other critical sectors which can make a valuable contribution to the economy and boost the growth potentials of Nigeria. To promote per capita income, a sound export policy needs to be promoted (Onayemi and Ishola cited in Ogunjimi, Aderinto, and Ogunro, 2015). It follows, therefore, from the above that economic diversification has the potentials to boost a country's balance of payment position through inflows from foreign exchange earnings.

\section{Economic Growth in Nigeria}

Economic growth can be simply defined as the sustained aggregate increment in the production activities, vis-à-vis goods and services, of an economy across a period (usually measured in years). From a population perspective, economic growth refers to the quotient of the aggregate production of goods and services in an economy in a given year by the total number of people residing in the country in question. The statement of economic growth can be presented in real or nominal terms. For instance, an aggregate level of increase in goods and services that are deflated for inflation is regarded as real economic growth. While nominal economic growth occurs when there is an aggregate level of increase in goods and services without deflation. 
Attaining sustainable economic advancement has been the aspiration of Nigeria leading to the adoption of different fiscal and monetary policies. Being a monolithic economy, which is heavily depended on oil revenue, Nigeria's economic growth has been greatly influenced by exogenous factors which were dominated by events in the world oil market. Over the years, rapid economic growth in Nigeria has been a mirage due to the country's inability to reduce drastically, the rate of poverty. Huge oil revenue has meant that more attention is given to the oil sector, while the non-oil sector with its abundant potentials is neglected.

Twenty per cent of Nigeria's GDP is accounted for by crude oil. Furthermore, 80 and 90 per cent of government revenue and foreign exchange earnings are derived from crude oil. What this implies is that Nigeria's economy is volatile and therefore susceptible to economic fluctuations resulting from variations in the world oil price (Joshua, Happy, and Dankumo, 2016). The role of non-oil sectors in reducing unemployment, poverty alleviation, and in promoting economic growth and national development cannot be overemphasized (Raj, 2002), because these non-oil sectors can supplement in improving the livelihood of the poor (Tunde, 2012). There have been fluctuations in the growth rate of oil real GDP during the period (1982-2015) which is attributed to dwindling oil prices in the international market, while stability was witnessed in the growth rate of non-oil real GDP (Joshua, et al., 2016). In 2013, non-oil GDP grew by $8.4 \%$ as opposed to the $5.8 \%$ recorded in 2012. A scholar expounded that this performance is attributable to the $21.7 \%$ growth of the industrial sector, followed by the $14.2 \%$ and $6.6 \%$ growth rates in construction, and trade/services activities respectively (Joshua, et al., 2016).

In the 1960 s, $60 \%$ of Nigeria's GDP was derived from the agricultural sector with peasant farming (using traditional tools and indigenous farming methods) accounting for more than 70\% of the nation's exports and providing 95\% of the food needed (Lawal, 1997). Regrettably, the potency of the agricultural sector today has drastically evaporated from a very dominant position where it contributed $55.8 \%$ to the GDP in $1960-70,28.4 \%$ in $1971-80$ before appreciating to $32.8,34.2$, and 40.3 contributed during $1981-90$, 1991-2000 and 2001-2009 respectively (Okezie and Amir, 2011). However, Sanusi (2010) attributed the fall and dwindling trends to the low productivity of agricultural activities in the country (as many players are peasant farmers who rely on mosaic farm implements and poor technology) and a weak industrial sector.

\section{Theoretical Framework}

In this work, the framework for understanding diversification and growth is rooted in three main theories, the Variety Hypothesis (for diversification), and the Neoclassical Growth Model and the Endogenous Growth model (for growth).

\section{The variety hypothesis}

The variety hypothesis provides an explanation for export diversification. It states that as real income increases, purchasers tend to buy more variety of products. The Nigerian economy is a monolithic one dominated by the oil sector, with an underdeveloped non-oil sector, and therefore imports most of its consumer and capital goods. Thus, a greater number of the variety of goods demanded are imported, and the quantity of imports in demand tends to be increasing more than proportionately with per capita income. The implication of this is that sustained growth can be achieved if a country produces a variety of or a diversified range of commodities for exports.

The variety hypothesis is criticized though, firstly, on the grounds that developing countries like Nigeria face growing difficulties in producing a diverse variety of commodities, thus suffering BOP deficits with minimal real growth over a long period of time. Secondly, the theory is more relevant to advanced economies which produce a diverse variety of products and possess superior technology (Nyong, 2015). Diversification aimed at the export sector would affect economic growth in the following four ways. First, through large-scale and improved production of goods in the non-oil sector, there would be available export products, especially if these resources are properly harnessed and efficiently managed. Secondly, it increases productivity by offering greater economies of scale which is necessary for large scale production of domestic goods and services. Thirdly, diversification for exports could be used to alleviate some constraints in the foreign exchange market, thereby providing better access to international trading partners. Fourthly, diversification for exports is likely to promote economic growth in the long-run by promoting technological innovation and allowing for dynamic learning from overseas.

\section{The Solow Neoclassical Growth Model}

The Solow Neoclassical Growth Model uses labour, capital accumulation, and increase in productivity to explain economic growth in the long-run. "The model is an alternative to the Harrod-Domar model. This model postulates "a continuous production function linking output to the inputs of capital and labour which are substitutable" (Acemoglu, 2009: 23). Labour and capital were separately examined in the neoclassical growth model through diminishing returns and constant returns to both factors jointly. In the model, a residual factor that explains long term growth level is technological progress.

Technological progress is also a key assumption responsible for the determination of exogenous growth, independent of all other factors in the model. The model predicted that increased savings will lead to a higher level of growth in the output of each worker; while an increasing rate of the labour force (adjusted for depreciation and technological process) has the opposite effect on growth. In the augmented Solow growth model, a human capital measure was added as an additional factor or determinant of growth (Heiko, 2008). The neoclassical model is criticized for not explaining the sources of technical change (Essien and Bawa cited in Uwakaeme, 2015).

\section{The Endogenous Growth Model}

This endogenous growth theory expressed a different conceptualization which distinguishes it from other neoclassical models of growth. Interestingly, the endogenous growth model prescribes that economic output is an aftermath of activities within an economic system and not from external activities. This implies that production, commercial and industrial activities which take place in an economy is what promotes economic and not from outside. This theory justifies the popular statement that "charity 
begins from home." Thus, any economy that must witness growth, must learn to harness her potentials internally and not rely on external activities. The central tenet of the theory is that through the accumulation of knowledge and capital within an economy, positive growth prospects are plausible as long as efforts are made to economize these resources. This theory recommends that nations venture into activities that can enhance economic efficiency since the technical efficiency of any nation is considered as a necessity for advancement. The theory also emphasized "learning by doing" in the technological process, implying that nations should adopt and develop technologies learnt from overseas. By further implication, this theory discourages reliance on technologies domiciled in other nations but encourage the acquisition of technological knowledge to apply in home countries with innovations to such knowledge. The theory also introduces the human capital, good governance and effective institutions as crucial factors necessary to boost the general growth potentials of an economy (Romer, 1994; Essien cited in Uwakaeme, 2015).

The importance of the endogenous growth theory is quite glaring because the growth of per capita output is traced to two main sources - efficiency and savings. In other words, efforts to utilize accumulated factors play a significant role in promoting economic growth as factor accumulation itself. One important economic implication of this theorization is the achievement of economic stability coupled with positive interest rate and low inflation, consequently spurring savings that are needed for growth to thrive (Contessi and Weinberger, 2009). Consequently, the theory considers whatever increases efficiency and savings as being very vital for growth. The theory also argued that even if policy measures do not alter dis-aggregate savings rate, it has a long-run implication on the growth rate of a nation's economy. Thus, countries with high levels of internal efficiency, strong economic system, and sound macroeconomic policies, tend to grow more rapidly (Romer, 1994).

\section{Empirical Studies}

Using a Granger Casualty Test, Olaleye, et al. (2013), studied export diversification and economic growth in Nigeria. The study disclosed that an increase in outputs of the agricultural sector will lead to a significant improvement in the welfare of the populace. A finding which aligns with the Rostow Stages of growth, which stipulated that increase in the agricultural sector is the first stage in every country's development path. According to Joshua et al, (2016), the issue of pricing in Nigeria's oil economy is a problem factor that is a recurring decimal. Arinze cited in Joshua et al (2016), discovered that oil prices are positively related to inflation. Furthermore, the author disclosed that the entire economy would witness shocks as long as there are shocks associated with oil prices, making the economy extremely vulnerable. A call was made for the conscious diversification and the expansion of the nonoil sectors in Nigeria.

A study found that poor management of human capital/resources encouraged migration as many talented citizens sought for greener pastures in other countries (Uzonwanne, 2015). The author detailed that the cause of this ugly situation is the over-reliance on oil as the major export commodity of the country. Furthermore, constant GDP depreciation in the country was attributed to the relegation of the agricultural sector making it plausible to diversify the Nigerian economy. Thus it was suggested that in order to stem the tide of the loss in human capital/resources as well as GDP depreciation, the government must create an enabling environment for diversification to thrive; institute a functional agricultural bank or a microfinance bank dedicated exclusively for farmers to access soft loans; subsidize agriculture; introduce mechanized systems of agriculture at all levels, and de-politicize the implementation of agricultural projects.

In their paper, Esu and Udonwa (2015) obtained time series data covering 1980 - 2011, with the econometric result based on error correction modelling framework. It was suggested that the way to go in maximizing gains from trade is conscious and honest efforts at diversifying the economy. Thus, targeted efforts should, therefore, be directed towards industrialization, which should be done through the creation of necessary infrastructures and opening up to investment opportunities that are technologically driven, with a heavy industrial base.

Through a study, Evbuomwan (2016) noted that despite the suboptimal performance of the agricultural and solid minerals sectors in Nigeria due to their neglect since the discovery of oil in the 1970s, these sectors still possess the capacity to put the country on a sustainable path of growth and development in view of the abundance of enormous resources yet to be tapped. According to her, a critical examination of available statistics reveals that in recent years agricultural sector contribution to GDP has improved (from 15.5 per cent of total GDP in 1981 to 23.1 per cent in 2015), while more agricultural commodities have entered the non-oil export list.

In another study, Ayodele, et al. (2013) identified the failure of past government solid mineral policy as well as previous government involvement in solid mineral exploration, as major setbacks in the growth and development of the solid mineral sector. He, therefore, suggested government action in the form of creating a conducive and socioeconomic environment which would facilitate both domestic and foreign investment in the solid minerals sector. Also, for Nigeria to attract investors in its solid minerals sector, the government must have correct geosciences data on the country's minerals which would include availability and quality of minerals (Olure-Bank \& Salako, 2016). Agriculture and tourism are imperatives for diversification (Eko et al., 2013). Since the discovery of oil in commercial quantities, the performance of the Nigerian economy has been dismal; with very little success from several attempts at reversing the trend. Thus, in concluding, they recommended the repositioning of the two sectors (agriculture and tourism) if optimum performance must be recorded for desired economic growth and development.

Tourism has a significant effect on sustainable development through the creation of income multiplier effect, employment, infrastructure and environmental development (Eneji, et al., 2016). Income earned by locals from tourists is spent in the local/domestic economy thereby boosting its growth. They also noted that $\$ 10$ billion annual projected income could be generated by Nigeria from the tourism industry. Such funds could be used to push the economy towards growth, considering the current GDP of the country. The authors recommended that it is reasonable for the government to derive income from other non-oil industries for improved GDP, making an investment in tourism a plausible option due to its multiplier consequences. 


\section{METHODS}

This study examines the impact of Economic Diversification and growth in Nigeria. The study adopts both descriptive and analytical research designs. Time series data from the period (1981-2016) was sourced from secondary sources. The data for this study has been obtained from the Central Bank of Nigeria statistical bulletin (CBN), Central Bank of Nigeria Annual Reports, World Development Indicators (WDI) of 2016 and 2017 respectively. In evaluating the impact of Economic Diversification and growth in Nigeria for the period 1981-2015 this study adopted the Ordinary Least Square (OLS) method of data analysis. The choice of this method stems from its basic features of being; Analytically simple to use; it is the best linear unbiased estimator (i.e.) the "BLUE" characteristics of the OLS.

\section{Specification of Model}

The theoretical foundation of this study is anchored on the endogenous growth model which assumes that continued growth in an economy is determined by the production of goods and services and the level of private domestic investment not by external factors as illuminated by (Romer, 1994) in the theoretical framework. Within the endogenous growth model, the impact of domestic investment and economic growth can be examined using the fundamental underpinnings of the endogenous growth model as stated above. The model in a linear form can be expressed as:

$$
G D P G R=f(N O G D P, N O E X P, I N V, E X C H, \mu)
$$

Equation (1) can be transformed into an econometric model of the form:

$$
G D P G R=b_{0}-\log b_{1} N O G D P+\log b_{2} N O E X P+\log b_{3} I N V-\log b_{4} E X C H+\mu
$$

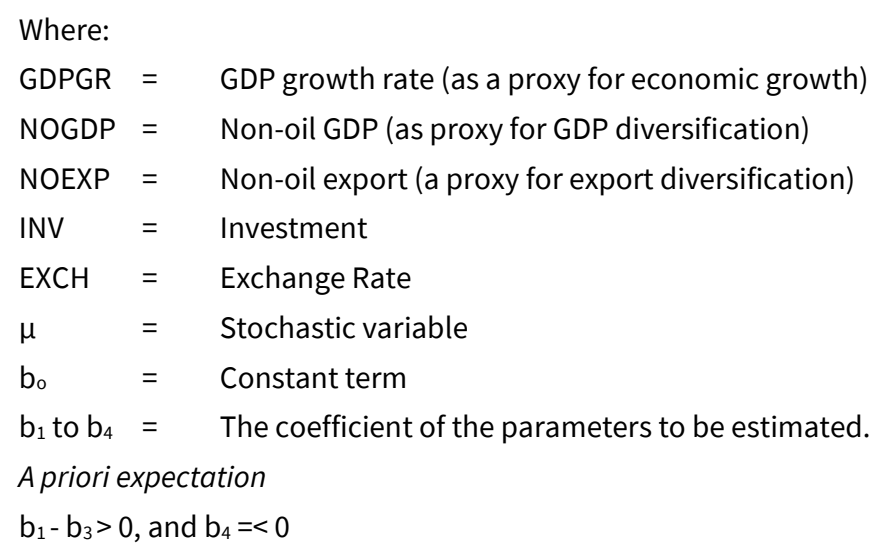

\section{Estimation Technique}

The estimation technique adopted for this study is the Ordinary Least Squares (OLS) regression approach. This approach was considered because it is the Best Linear Unbiased Estimator (BLUE), and has been widely used in the literature by experts in econometric studies and in studies utilizing time-series (panel) data due to its high efficiency in minimizing errors. Furthermore, the OLS is characterized by such core but salient features as, efficiency, un-biasedness, BLUE, minimum variance, least means square error and sufficiency vis-à-vis other econometric approaches.

\section{Procedures for Data Analysis}

The model above will be analyzed using three criteria, namely, economic a priori criteria, statistical criteria and econometric criteria.

\section{Economic a priori criteria}

This is determined by economic theory and refers to the sign and the size of the parameters of the economic relationship. In other words, it is concerned with ascertaining the degree of estimates conformity to the stated norms or signs predicted by related economic theory. When results obtained yield estimates that do not conform to prescribe economic outcomes stated in theories, then such estimates would be rejected. However, in situations where good reasons are presented with strong literature support that such theoretical provisions do not hold, then an estimate which contradicts known theoretical knowledge may be upheld.

\section{a. Statistics Criteria (first-order test)}

The measures used to test the statistical significance of parameters of this study include: the t-Statistics, the $\mathrm{R}^{2}$ and Adjusted $\mathrm{R}^{2}$ and the F-Statistics

\section{b. Econometric criteria (Second - Order test)}

Econometrics criteria are set by the theory of econometrics with the aim of testing the assumptions of the econometric procedures adopted and to determine whether they are satisfactory or not. This criterion serves as the second-ordered test. Put differently, the econometric criterion is used to determine the reliability of the statistical criteria, particularly the standard errors of the estimates. They assist in testing for the unbiasedness and consistency as desirable properties of estimates. Therefore, for 
Table 1. Ordinary Least Squares Regression Results showing the effect of Economic Diversification on Economic growth in Nigeria

\begin{tabular}{|c|c|c|c|c|}
\hline Variable & Coefficient & Std. Error & t-Statistic & Prob. \\
\hline $\mathrm{D}(\mathrm{LOG}[\mathrm{NONGDP}])$ & 18.53518 & 9.407887 & 1.970175 & 0.0581 \\
\hline $\mathrm{D}(\mathrm{LOG}[\mathrm{NOEXP}])$ & 3.148362 & 2.471988 & 1.273616 & 0.2126 \\
\hline $\mathrm{D}(\mathrm{LOG}[\mathrm{INV}])$ & 3.021437 & 3.706551 & 0.815161 & 0.4214 \\
\hline $\mathrm{D}(\mathrm{LOG}[\mathrm{EXCH}])$ & -9.397788 & 3.807558 & -2.468192 & 0.0195 \\
\hline $\mathrm{C}$ & 5.127909 & 1.499398 & 3.419978 & 0.0018 \\
\hline
\end{tabular}

R-Squared $=0.5758$

Adjusted R-Squared $=0.499296$

F-Statistic $=2.856966$

Durbin-Watson Statistic $=1.971016$

the purpose of this study, since the OLS technique was employed to obtain the estimates of the model, the test for the absence of autocorrelation is conducted using the Durbin - Watson statistics.

\section{RESULTS}

According to the results in Table 1, all the variables were consistent with their a priori expectation. This implies that a unit change in the non-oil gross domestic product (NOGDP), non-oil export (NOEXP), and investment (INV), will lead to an increase of $18.54 \%, 3.15 \%$ and $3.02 \%$ on economic growth in Nigeria respectively. Also, a unit change in the exchange rate (EXCH), will instigate a reduction in the level of economic growth in Nigeria by $9.40 \%$. The result reveals that non-oil GDP has the highest effect on economic growth within the period of analysis.

\section{Statistical Criteria}

From the result presented in Table 1, non-oil gross domestic product-D(LOG(NOGDP)) and exchange rate D(LOG(EXCH)) were statistically significant. While NOGDP was statistically significant at the $10 \%$ level of significance, EXCH was significant at the $5 \%$ level of significance. They were significant because their t-statistic calculated of 1.97 and -2.47 is greater than the t-statistic tabulated of 1.697 at the $10 \%$ level of significance and 2.042 at the $5 \%$ level of significance respectively. The other explanatory variables NOEXP and INV were statistically insignificant since their t-statistic calculated of 1.27 and 0.82 were less than the tstatistic tabulated of 2.042 and 1.697 at the $10 \%$ and $5 \%$ levels of significance respectively. The adjusted R-squared of 0.499296 shows that about $50 \%$ of the total variation in economic growth is accounted for by the factors adopted in the study, leaving the remaining $50 \%$ for other factors not considered in the study. The result further indicates that the F-statistic estimate of 2.856966 is greater than the F-statistic calculated of 2.53 . Therefore, we conclude that the F-statistics is statistically significant at the $5 \%$ level of significance, and hence, the model has a good fit and can be relied upon in forecasting the trend of economic growth in Nigeria.

\section{Econometric Criteria}

From the result of Durbin-Watson estimate of 1.971016, the result falls on the No-autocorrelation region, thus we conclude that there is no autocorrelation in our result estimate.

\section{Test of Hypothesis}

Restatement of formulated hypotheses is as follows:

a. $H_{01}$ : GDP diversification proxy by non-oil GDP do not have a significant impact on economic growth in Nigeria. Based on the estimated result, the non-oil gross domestic product was statistically significant at the $10 \%$ level of significance. Hence, we reject $\left(\mathrm{H}_{\circ 1}\right)$ and accept $\left(\mathrm{H}_{1}\right)$ that GDP diversification has a significant impact on economic growth in Nigeria.

b. Ho2: Export diversification proxy by non-oil export do not have a significant impact on economic growth in Nigeria. From the estimated result, non-oil export was statistically insignificant at both the $5 \%$ and $10 \%$ levels of significance. Therefore, we accept $\left(\mathrm{H}_{02}\right)$ and conclude that non-oil exports have no significant impact on economic growth in Nigeria. To justify the direction of the result of this hypothesis, we tested for multicollinearity among the independent variables in the model to be sure if the insignificance of the results was not due to high correlation among the variables in the model. Pearson product moment correlation was used to examine the relationships among the variables. The results revealed ( $r$ ) coefficients ranging from .04 to .3 , which are weak coefficients suggesting that there is no problem of multicollinearity in the time series data set.

\section{DISCUSSION OF FINDINGS}

The diversification of the Nigerian economy demands active involvement of the other sectors of the economy other than the oil sector. This is important in order to enhance robust growth as well as maximize existing potentials in the different sectors of the Nigerian economy. However, this study was aimed at examining diversification and economic growth in Nigeria. From the analysis, the study found that non-oil gross domestic product, non-oil export and investment impacted positively on economic growth, but it was only the impact of non-oil gross domestic product was statistically significant within the period of analysis. This 
finding corroborates the outcomes of studies (Ayodele et al., 2013; Eko et al., 2013; Evbuomwan, 2016), that increased non-oil output is critical in the diversification of the Nigerian economy. It means, therefore, that any policy aimed at diversifying the economy must consider avenues for increasing productivity in the other sectors of the economy. One of the ways to achieve this is through an appropriate exchange rate policy. This is due to the fact that exchange rate impacted positively and significantly on economic growth in the study. Therefore, the exchange rate is one of the critical factors that will enhance diversification. Non-oil export production and investment opportunities are not adequate to exert significant influence on economic growth within the period of the analysis.

\section{CONCLUSION}

Economic diversification has been a recurring decimal in the history of the Nigerian economy. This is due to the fact that it has the capacity to identify and unleash the inherent potentials in the other sectors of the economy yet untapped, aside from the oil sector. Economic diversification has been argued to be critical in achieving sustainable and stable growth of the Nigerian economy. This study was an attempt to assess the impact of economic diversification on economic growth in Nigeria. An econometric approach was used to empirically assess the contributions of non-oil gross domestic product and non-oil export as the key to economic diversification in Nigeria. This study focused on non-oil gross domestic product and non-oil export as proxies for economic diversification. From the empirical results, we discovered that: non-oil gross domestic product impacted positively and significantly on economic growth; non-oil export and investment exerted a positive but non-significant effect on the economic growth of Nigeria; the exchange rate had an inverse but significant impact on economic growth in Nigeria.

The outcome of this study indicates that the real sector outcomes are key in accelerating economic growth in Nigeria. This, therefore, shows that economic diversification is relevant for achieving sustained and stable economic growth in Nigeria. However, achieving sustained and stable economic growth has also been seen to be dependent on the level of the exchange rate. By and large, the study discovered that within the period of analysis, economic diversification is vital in enhancing economic growth in Nigeria. These reveal that the achievement of economic diversification in Nigeria must be leveraged on how to increase the non-oil export output as well as a stable exchange rate policy. Judging from the findings of the study, the following recommendations are relevant in stimulating economic diversification and economic growth in Nigeria.

a. For the solid minerals sector to become a major player in the economy in the coming decades, with value addition along the value chain, the government should provide the support that will induce greater entrepreneurial and investments effectiveness/efficiency in harnessing available mineral resources and related economic activities to promote income generation, poverty alleviation, job creation and inclusive economic growth.

b. Existing policies and incentives should be reviewed and strengthened to facilitate the rapid economic growth of non-oil sectors. The current state of infrastructure such as electricity, transport, ports, financial services infrastructure should be improved because the survival of SMEs (which constitute the bulk of the non-oil sector) depends to a reasonable extent on this.

c. Government's should channel efforts towards creating international awareness on the business and investment opportunities available in Nigeria in non-oil areas such as agriculture, manufacturing and solid mineral. Currently, investments efforts in Nigeria is directed mainly at oil- and energy-related sectors. It is also important to note that largescale solid mineral exploration can best be financed by foreign investors, who have both the finance and expertise.

d. Targeted efforts should be directed towards industrialization. This should be done through the creation of necessary infrastructures (such as good and durable road network; standard railway lines for passenger and cargo especially in large commercial cities and between large sources of raw materials and production centres as well as between production centres and the seaports; construction of seaports along the coastlines as well as inland ports for onward transfer of cargo inland; passenger and cargo airports; modern communication infrastructure, among others), and opening up to investment opportunities that are technologically driven, with a heavy industrial base.

e. The right macroeconomic environment should also be created to encourage sustained investment. The progress made in developing a working and activity-driven agricultural, manufacturing and solid mineral sub-sectors, should be progressive and sustainable. In addition, the right political and social environment that symbolizes a committed and total battle against corruption and insecurity should be ensured.

f. The government should use infrastructural support driven by efficiency, enhanced technology and a strong institutional/economic reform to enhance the human capital stock of Nigerian for increased production capacity.

\section{REFERENCES}

Acemoglu, D. (2009). The Solow Growth Model: Introduction to modern economic growth. Princeton: Princeton University Press.

Agbaeze, E. K., Udeh, S. N. and Onwuka I. O. (2015). Resolving Nigeria's dependency on oil - The derivation model. Journal of African Studies and Development, 7(1), 1-14. https://doi.org/10.5897/JASD2014.0303

Ayodele, O. S., Akongwale, S. and Udefuna P. N. (2013). Economic diversification in Nigeria: Any role for solid mineral development? Mediterranean Journal of Social Sciences, 14(6), 691-703. https://doi.org/10.5901/mjss.2013.v4n6p691 
Contessi, S., \& Weinberger, A. (2009). Foreign direct investment, productivity, and country growth: An overview. Federal Reserve Bank of St. Louis Review, 91(2), 61-78. https://doi.org/10.20955/r.91.61-78

Eko, S. A., Utting, C. A. and Onun, E. U. (2013). Beyond oil: Dual-imperatives for diversifying the Nigerian economy. Journal of Management and Strategy, 4(3), 81-93. https://doi.org/10.5430/jms.v4n3p81

Ekpo, A. H. and Umoh, O. J. (2014). An Overview of the Nigerian economic growth and development. Available at: https://www.onlinenigeria.com/economics

Eneji, M. A., Odey, F. A. and Bullus, M. L. (2016). Diversification of Nigeria's economy: Impact of tourism on sustainable development in Nigeria. International Journal of Research in Humanities and Social Studies, 3(5), 36-44. Available at: https://www.ijrhss.org/pdf/v3-i5/6.pdf

Esu, G. E. and Udonwa, U. (2015). Economic diversification and economic growth: Evidence from Nigeria. Journal of Economics and Sustainable Development, 6(16), 56-68. Available at: https://tinyurl.com/ruchumk

Evbuomwan, G. O. (2016). Diversification of the Nigerian economy: Agriculture and solid minerals as a panacea. BULLION: Publication of the Central Bank of Nigeria, 1-40(1976-2016), 50-62. Available at: https://tinyurl.com/sdssogl

Heiko, H. (2008). Export diversification and economic growth. Working paper No. 21 of the commission on growth and development. The International Bank for Reconstruction and Development/The World Bank On behalf of the Commission on Growth and Development. Washington DC: World Bank. Available at: https://tinyurl.com/tlc6tr2

Jide, I. (2017). Keystone bank boosts agriculture with N300m Agric anchor borrowers programme. Available at: https://tinyurl.com/qraptst

Joshua, S. R., Happy, D. G. and Dankumo, A. M. (2016). Growth of non-oil sectors: A key to diversification and economic performance in Nigeria. Public Policy and Administration Research, 6(3), 64-75. Available at: https://tinyurl.com/qmnqyo4

Lawal, A. A. (1997). The Economy and the State from the Pre-colonial Times to the Present. In A. Osuntokun and A. Olukoju (Eds), Nigerian peoples and cultures. Ibadan: Davidson.

Nyong, M. O. (2015). International Economics: Theory, policy and application. Calabar, Nigeria: Wusen Publishers.

Ogunjimi, O., Aderinto, E. and Ogunro, T. (2015). An empirical analysis of the relationship between non-oil exports and economic growth in Nigeria. International Journal of Academic Research in Business and Social Sciences, 5(12), 68-78. https://doi.org/10.6007/IJARBSS/v5-i12/193

Ojiabor, F. (2014). Oil and the diversification of Nigeria's economy, around Nigeria. Available at: https://www.publicaffairs.gov.ng

Okezie, C. A. and Amir, B. H. (2011). Economic crossroads: The experiences of Nigeria and lessons from Malaysia. Journal of Development and Agricultural Economics, 3(8), 368-378. Available at: https://tinyurl.com/saej9ht

Olaleye, S. O. Edun, F. and Taiwo, S. B. (2013). Export diversification and economic growth in Nigeria: An empirical test of relationship using a Granger Casualty Test. Journal of Emerging Trends in Economics and Management Sciences (JETEMS), 5(1), 70-79. Available at: https://tinyurl.com/yx36xg3y

Olorunfemi, F. and Raheem, U.A. (2008). Sustainable tourism development in Africa: the imperative for tourist/host communities' security. Journal of Sustainable development in Africa, 10(3), 201-220. Available at: https://tinyurl.com/lvobbr

Olure-Bank, A. M. and Salako G. (2016). Economic gift source of diversifying Nigerian economy for economic growth and economic development sustainability. Journal of Economics and Sustainable Development, 7(11), 34-42. https://doi.org/10.1057/978-1137-59403-7_2

Oyejide, T. A. (1986). The effects of trade and exchange rate policies on agriculture in Nigeria. Research Report 55. International Food Policy Research Institute, Washington, DC

Raj, K. (2002). A modern dictionary of tourism. New Delhi: Ivy Publishing House.

Romer, P. M. (1994). The origins of endogenous growth. The Journal of Economic Perspectives. 8(1), 3-22. https://doi.org/10.1257/jep.8.1.3

Sanusi, L. S. (2010). Growth prospects for the Nigerian economy. Convocation lecture presented at the Igbinedion University Eighth Convocation Ceremony, Okada, Edo State, 26 November 2010. Available at: https://www.bis.org/review/r101210e.pdf

Suberu O. J., Ajala O. A., Akande M. O. and Olure-Bank A. (2015). Diversification of the Nigerian economy towards sustainable growth and economic development. International Journal of Economics, Finance and Management Sciences, 3(2), $107-114$. https://doi.org/10.11648/j.ijefm.20150302.15

Tunde, A. M. (2012). Harnessing tourism potentials for sustainable development: A case of Gurara waterfalls in Nigeria. Sustainable Development in Africa, 14(1), 119-133. Available at: https://tinyurl.com/w5465aw

Uwakaeme, O. S. (2015). Economic growth in Nigeria: An empirical investigation of determinants and causal relationship (1980 2012). American Journal of Economics, 5(1), 9-20. https://doi.org/10.5923/j.economics.20150501.02

Uzonwanne, M. C. (2015). Economic diversification in Nigeria in the face of dwindling oil revenue. Journal of Economics and Sustainable Development, 6(4), 61-67.

World Bank (2000). Partnerships for development: The World Bank. Washington, D. C: The Creative Communications Group. 


\section{APPENDIX}

\begin{tabular}{|c|c|c|c|c|c|}
\hline Year & $\begin{array}{c}\text { Non-OiL GDP } \\
\text { (At } 1990 \text { constant basic } \\
\text { prices) } \\
=\mathrm{N}=\text { Million }\end{array}$ & $\begin{array}{l}\text { Non-Oil Exports } \\
\text { (At } 1990 \text { constant } \\
\text { basic prices) } \\
=\mathrm{N}=\text { Million }\end{array}$ & $\begin{array}{l}\text { Investment } \\
\text { (Gross Fixed } \\
\text { Capital Formation } \\
\text { as proxy) } \\
=\mathrm{N}=\text { Million }\end{array}$ & $\begin{array}{c}\text { Exchange Rate } \\
\text { Average annual } \\
\text { exchange rate of the } \\
\text { Naria vis-à-vis the US } \\
\text { Dollar } \\
=\mathrm{N}=\text { US } \$ 1.00\end{array}$ & $\begin{array}{c}\text { Annual GDP Growth } \\
\text { Rate (\%) }\end{array}$ \\
\hline 1981 & $178,032.60$ & 0.3 & $18,220.60$ & 0.61 & -13.1279 \\
\hline 1982 & $181,398.20$ & 0.2 & $17,145.80$ & 0.6729 & -1.05319 \\
\hline 1983 & $170,922.80$ & 0.3 & $13,355.30$ & 0.7241 & -5.05045 \\
\hline 1984 & $160,370.40$ & 0.2 & $9,149.80$ & 0.7649 & -2.02154 \\
\hline 1985 & $180,861.30$ & 0.5 & $8,779.50$ & 0.8938 & 8.32283 \\
\hline 1986 & $186,993.50$ & 0.6 & $11,351.50$ & 2.0206 & -8.75418 \\
\hline 1987 & $186,982.20$ & 2.2 & $15,228.60$ & 4.0179 & -10.7517 \\
\hline 1988 & $204,571.80$ & 2.8 & $17,562.20$ & 4.5367 & 7.542522 \\
\hline 1989 & $215,768.90$ & 3 & $26,825.50$ & 7.3916 & 6.467191 \\
\hline 1990 & $322,903.80$ & 3.3 & $40,121.30$ & 8.0378 & 12.76601 \\
\hline 1991 & $237,330.60$ & 4.7 & $45,190.20$ & 9.9095 & -0.61785 \\
\hline 1992 & $243,674.60$ & 4.2 & $70,809.20$ & 17.2984 & 0.433725 \\
\hline 1993 & $248,730.40$ & 5 & $96,915.50$ & 22.0511 & 2.090378 \\
\hline 1994 & $253,841.10$ & 5.3 & $105,575.50$ & 21.8861 & 0.909763 \\
\hline 1995 & $259,109.50$ & 23.1 & $141,920.20$ & 21.8861 & -0.30747 \\
\hline 1996 & $266,979.10$ & 23.3 & $204,047.60$ & 21.8861 & 4.993706 \\
\hline 1997 & $276,113.80$ & 29.2 & $242,899.80$ & 21.8861 & 2.802256 \\
\hline 1998 & $284,544.60$ & 34.1 & $242,256.30$ & 21.8861 & 2.71564 \\
\hline 1999 & $296,978.00$ & 19.5 & $231,661.70$ & 92.6934 & 0.474238 \\
\hline 2000 & $305,504.50$ & 24.8 & $331,056.70$ & 102.2052 & 5.318093 \\
\hline 2001 & $319,365.80$ & 28.0 & $372,135.70$ & 111.9433 & 4.411065 \\
\hline 2002 & $345,783.60$ & 94.7 & $499,681.50$ & 120.9702 & 3.784648 \\
\hline 2003 & $363,670.60$ & 94.8 & $865,876.50$ & 129.3565 & 10.35418 \\
\hline 2004 & $391,905.30$ & 113.3 & $863,072.60$ & 133.5004 & 33.73578 \\
\hline 2005 & $425,698.20$ & 106.0 & $804,400.80$ & 131.6619 & 3.444667 \\
\hline 2006 & $465,628.04$ & 133.6 & $1,546,525.70$ & 128.6516 & 8.210965 \\
\hline 2007 & $510,000.00$ & 199.3 & $1,936,958.21$ & 125.8331 & 6.828398 \\
\hline 2008 & $555,600.00$ & 525.9 & $2,053,005.95$ & 118.5669 & 6.270264 \\
\hline 2009 & $601,900.00$ & 500.9 & $3,050,575.92$ & 134.6135 & 6.934416 \\
\hline 2010 & $653,100.00$ & 711.0 & $4,012,918.65$ & 150.66 & 7.839739 \\
\hline 2011 & $710,900.00$ & 913.5 & $3,908,280.32$ & 158.27 & 4.887387 \\
\hline 2012 & $802,140.00$ & 879.3 & $3,357,397.77$ & 157.33 & 4.279277 \\
\hline 2013 & $902,793.97$ & $1,130.20$ & $1,147,809.00$ & 157.26 & 5.394416 \\
\hline 2014 & $954,800.00$ & 953.5 & $1,359,958.40$ & 169.68 & 6.309718 \\
\hline 2015 & $676,770.00$ & 660.7 & $1,411,218.00$ & 193.28 & 2.652694 \\
\hline 2016 & $815,785.00$ & 656.8 & $1,470,244.00$ & 253.49 & -1.54106 \\
\hline
\end{tabular}

